\title{
MOTIVES FOR COMMENCING STUDIES AND EXPECTATIONS CONCERRING PROFESSIONAL COMPEEENCE IN STUDENTS WHO PRACTICE, USED TO PRACTICE OR HAVE NEVER PRACTICED SPORTS
}

\author{
Mariola Radzińska, 1, A, B, D Leonard Nowak, 1, B, D, E Maria Alicja Nowak², A, C, D \\ ${ }^{1}$ Faculty of Physical Culture in Gorzow Wielkopolski, University School of Physical Education in Poznan \\ ${ }^{2}$ Faculty of Physical Culture and Health Promotion, University of Szczecin, Szczecin

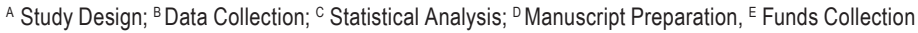 \\ Address for coprespondence: \\ Maria Alicja Nowak \\ University of Szczecin, Faculty of Physical Culture and Health Promotion \\ Al. Piastów 40b, building 6, 71-065 Szczecin, Poland \\ E-mail: maria-nowak@wp.pl
}

\begin{abstract}
Ahstract. Aim: Economic development, connected with the concept of a society engaged in lifelong learning, demands that education produce optimal professional competences. The aim of this study was to determine the motives for the choice of physical education studies, and ascertain expectations concerning professional competences, as well as self-evaluation of competences acquired, in current and former athletes and non-athletes.

Methods. 226 people were examined, all studying physical education at the Faculty of Physical Culture in Gorzow Wielkopolski, a branch of the University School of Physical Education in Poznan. Purposive sampling was used (Radzińska, Nowak, L., Nowak, M., 2013). The study included current $(22.6 \%)$ and former athletes $(31.8 \%)$ as well as non-athletes $(45.6 \%)$. A diagnostic survey was employed, with the use of the techniques of auditorium questionnaire, interview and document analysis. In order to draw statistical conclusions, the trait frequency and the independence $x^{2}$ test were used.

Results. Former athletes more often reported having been motivated to choose the studies by their interest in employment with institutions of physical culture while non-athletes by their wish to obtain jobs in schools $(p \leq 0.05)$. Expectations of competence in physical education methodology were indicated by all respondents, slightly more often by former athletes and non-athletes $(p \leq 0.05)$. For current athletes, competence in physical fitness was important. Psycho-pedagogical competence in motivating schoolchildren to work was expected by most students $(84.5 \%)$, slightly more often by former athletes and non-athletes $(p \leq 0.05)$. Respondents rated their preparation for employment with regard to foreign languages and preparation for scientific work as average and fair, and their selfeducation ability and computer skills as good.
\end{abstract}

Key WOrdls: physical education students, current athletes, former athletes, non-athletes, motives, competence, expectations, self-evaluation 


\section{Introduction}

In the lifelong process of education (Ferenz, 2010) there is a clear differentiation of the particular stages in the context of objectives and ways to achieve them. According to the concept of psychosocial development (Erikson, 2004), each stage in the life of man has its tasks. The development task of the study stage involves gaining and improving knowledge, crystallization of professional competences, shaping of identity, determining career plans. In the Lisbon Declaration, professional competences, including social competence, were considered crucial for citizens of European Union Member States. They represent a specific combination of humanistic knowledge, engaging in relationships and community activities, capacity for free choice and critical judgment (Salmela-Aro, Tolvanen, Nurmi, 2009).

The purpose of modern education, which is based on the humanistic training model, is the creation of a student's personality in accordance with the adopted education outcomes and societal demand. In this context, the process of checking the quality of education should be consistent with the learning outcomes set out in the National Qualification Framework (hereinafter referred to as NQF) and the descriptors of the Bologna process (Kraśniewski, 2004; Cieśliński, 2009). In a study summarizing the implementation of the NQF in higher education institutions, the resulting benefits were clearly exposed, e.g. programs targeted on the achievement of learning outcomes, changes in curricula, changes in the content of programs and their adaptation to the learning outcomes, changes in the organization of curricula (expanding the offer of subjects to choose), changes in the way classes are conducted (increase in the number of classes focused on acquiring skills, conducted in active forms) (Kraśniewski, Próchnicka, 2013).

The portrait of a graduate in physical education specifies that they receive basic knowledge and skills in the area of social sciences, natural sciences and physical education, enabling them to competently influence man's personality and organism in order to meet their needs with respect to physical and motor development, as well as those related to participation in physical culture (www.bip.gov.pl, 10.11.2015). Participation in culture is believed to play a significant role (Kotarska, Wunsch, Raszeja-Wyszomirska, Kempińska-Podhorecka, Wójcicki, Milkiewicz, 2015). Finnish research has repeatedly confirmed that people who had been physically active in the past, i.e. former athletes, are much more likely to take up physical activity in adulthood than non-athletes (Telama, Laakso, Yang, 1994; Telama, Xiaolin, Laakso, Viikari, 1997). Such a division was adopted in this work (current athletes, former athletes, non-athletes).

In accordance with the present core curriculum, there are four hours of physical education, including two hours realized on facultative basis (www.reformaprogramowa.men.gov.pl; 5.12.2015). A school physical education program structured in this way allows students to develop their interests, as it covers variously profiled activities related to recreation and health, dance, tourism or sports. Diversification of the educational offer in this area obliges a future teacher to acquire specific competence. A young person's decision to commence studies in a given field should be matched with training oriented toward entering a particular profession, and meeting, at least in part, expectations of the student as far as the knowledge and skills acquired are concerned (Buchta, 2009; Radzińska et al., 2013).

Dynamic economic development is associated with the concept of a society engaged in lifelong learning. These connections pose challenges for the educational system and the modern labor market (Eider, 2009; Buchta, 2012; Czerepaniak-Walczak, 2013). Meeting these challenges makes it imperative to discover and train those skills which 
will most effectively facilitate running a successful career. Cooperation with a schoolchild and preparing them for self-reliant work on their fitness and health in the future, requires specific competence. This competence is related to substantive knowledge of the subject taught, and psycho-pedagogical, methodological and communication skills (Kwiatkowska, 2008; Jagusz, 2011).

The aim of this study was to determine the motives for the choice of physical education studies, and ascertain expectations concerning professional competences, as well as self-evaluation of competences acquired, in current and former athletes and non-athletes.

The following hypotheses were formulated:

1. For current athletes the main motive for the choice of physical education studies was the desire to work in institutions of physical culture, and for non-athletes it was employment in schools.

2. Expectations of specialist competence in knowledge and skills related to physical education methodology were more often indicated by non-athletes.

3. Psycho-pedagogical competence in motivating schoolchildren to work was expected by all students.

4. Respondents most often rated their preparation for employment as average and fair.

\section{Research material and methods}

Research into the quality of teaching in particular institutions of higher education stems from the guidelines of the Bologna process. The results of this study are part of the evaluation of education quality carried out by students of the Faculty of Physical Culture of the Poznan University School of Physical Education. The study included 226 people (48.7\% women and 51.3\% men), second and third-year undergraduate students and first-year postgraduate students in the field of physical education. Purposive sampling was used. A detailed description of the research was presented in the previous work (Radzińska et al., 2013). Three groups within each year-group were studied (male, female and mixed). The respondents lived mainly in urban areas (71.9\%) and reported a very good or average material situation ( $54.1 \%$ and $36.2 \%$ respectively). Of the 226 people surveyed, 123 had practiced sports at competitive level before commencing their studies. Currently 51 students continued training (22.6\%), 72 people had stopped training (31.8\%), and 103 people declared not having trained at all (45.6\%).

In the research, a diagnostic survey was employed, with the use of the techniques of auditorium questionnaire, uncategorized interview, and document analysis. In the design of the questionnaire the concept of the triple dimension of teachers' professional competence was used (Hamer, 1994). The first dimension embraces knowledge and skills related to the subject taught (specialist competences), the second and third ones concern the pedagogical and psychological skills, which are combined into psycho-pedagogical skills. The empirical material was statistically analyzed according to the number and characteristics of the variables (Van Buurren, de Leuve, 1992). In order to draw statistical conclusions, the trait frequency and the independence $X^{2}$ test were used. For the calculations the Statistica 10.0 software package was used (StatSoft, Inc., USA).

\section{Research results}

\section{Motives for the choice of the studlies}

For greater clarity of the results presented, the respondents were divided into three groups, and the following abbreviations were used in the tables: CA - students who currently practiced sports at competitive level - current 
athletes $(n=51), F A$ - students who used to practice sports at competitive level in the past - former athletes $(n=72)$, NA - students who had never practiced sports at competitive level - non-athletes ( $n=103)$.

Most people's reasons for the choice of physical education studies were: having athletic predispositions, the prospect of an interesting job, being interested in physical recreation, possibilities for self-realization and development of an athletic career. These choices had no connection with belonging to the above mentioned groups (Table 1).

Table 1. Motives for the choice of physical education studies among current and former athletes and non-athletes

\begin{tabular}{|c|c|c|c|c|c|}
\hline \multirow{3}{*}{ Motives for the choice of physical education studies } & \multicolumn{3}{|c|}{ Student categories } & \multirow{2}{*}{\multicolumn{2}{|c|}{ Total $(n=226)$}} \\
\hline & \multirow{2}{*}{$\mathrm{CA}(\mathrm{n}=51)$} & \multirow{2}{*}{$\begin{array}{c}\mathrm{FA}(\mathrm{n}=72) \\
\%\end{array}$} & \multirow[t]{2}{*}{$N A(n=103)$} & & \\
\hline & & & & $\mathrm{n}$ & $\%$ \\
\hline Having athletic predispositions & 26.0 & 30.0 & 44.0 & 100 & 44.2 \\
\hline Prospect of an interesting job in sport & 30.1 & 32.5 & 37.3 & 83 & 36.7 \\
\hline Being interested in physical recreation & 26.9 & 23.1 & 50.0 & 78 & 34.5 \\
\hline Need for self-realization & 20.0 & 32.9 & 47.1 & 70 & 30.1 \\
\hline Possibilities for development of an athletic career & 31.2 & 32.8 & 35.9 & 64 & 28.3 \\
\hline Desire to work in other institutions of physical culture* & 29.5 & 43.1 & 27.2 & 44 & 19.4 \\
\hline Conviction of the necessity to gain qualifications & 12.2 & 34.1 & 53.6 & 41 & 18.4 \\
\hline Necessity to gain a higher education & 23.6 & 28.9 & 47.3 & 38 & 16.8 \\
\hline Desire to work in school* & 35.1 & 16.2 & 48.6 & 37 & 16.3 \\
\hline Conviction of the attractiveness of the studies* & 21.6 & 48.6 & 29.7 & 37 & 16.3 \\
\hline Conviction of a high social prestige of the teaching profession & 22.8 & 34.2 & 42.8 & 35 & 15.4 \\
\hline Desire to follow one's physical education teacher's example & 16.6 & 33.4 & 50.0 & 18 & 7.9 \\
\hline Friends and acquaintances' persuasion & 0.0 & 33.3 & 66.6 & 15 & 6.6 \\
\hline
\end{tabular}

Note: Value of $p$ for the $x^{2}$ test was marked as follows: ${ }^{*} p \leq 0.05$.

Statistically significant correlations were found concerning the desire to work in school, in institutions of physical culture (in sports clubs, sports associations, administration, private fitness clubs) and the conviction of the attractiveness of the studies, among current and former athletes, as well as non-athletes (in each case the value of $p \leq 0.05$ for the $x^{2}$ test). The desire to work in school was declared to be an important motive for commencing the studies mostly by non-athletes (48.6\%). Being interested in employment in other institutions of physical culture was most often indicated by former athletes (43.1\%). For former athletes the conviction of the attractiveness of the studies was also a significant motive (48.6\%). It can be also observed that only $16.3 \%$ of the total of the subjects associated their choice of the studies with the desire to work in school, and $19.4 \%$ in institutions of physical culture.

The desire to follow the example of respondents' physical education teachers and their friends and acquaintances' persuasion were least often mentioned as motives for the choice of physical education studies.

\section{Students' expectations of specialist and psycho-pedayogical competences}

The studying period involves acquiring knowledge, skills and attitudes, in other words specific competences. Students' expectations in that respect concern specialist competences connected with their field of studies (Table 2) and psycho-pedagogical competences (Table 3). Statistically significant correlations were found with respect to expectations of knowledge and skills related to physical education methodology among current and former athletes 
and non-athletes (value of $p \leq 0.05$ for the $x^{2}$ test). These competences were more often indicated by those who had practiced sport at competitive level in the past (86.1\%) and those who had never practiced sport (86.4\%). For all respondents significant were also skills in conducting recreational activities and activities in chosen sports disciplines. Students also expected to acquire skills related to planning and realization of physical education classes, as well as facultative activities. The fewest indications concerned competences connected with theoretical knowledge of physical culture and a high level of physical fitness. Current athletes, who displayed the highest level of physical fitness, expected its improvement.

Tahle 2. Expectations of specialist competences among current and former athletes and non-athletes

\begin{tabular}{|c|c|c|c|c|c|}
\hline \multirow{3}{*}{ Specialist competences } & \multicolumn{3}{|c|}{ Student categories } & \multicolumn{2}{|c|}{ Total $(n=226)$} \\
\hline & $C A(n=51)$ & $\mathrm{FA}(\mathrm{n}=72)$ & $N A(n=103)$ & \multirow{2}{*}{$\mathrm{n}$} & \multirow{2}{*}{$\%$} \\
\hline & \multicolumn{3}{|c|}{$\%$} & & \\
\hline Knowledge and skills related to physical education methodology* & 70.5 & 86.1 & 86.4 & 187 & 82.7 \\
\hline Skills in conducting recreational activities & 62.7 & 63.8 & 66.9 & 147 & 65.0 \\
\hline Skills in conducting activities in a chosen sports discipline & 68.6 & 63.8 & 61.7 & 144 & 63.7 \\
\hline Skills in planning and realization of physical education classes and facultative activities & 62.7 & 59.7 & 60.1 & 137 & 60.6 \\
\hline A high level of physical fitness & 62.7 & 43.0 & 48.5 & 113 & 50.0 \\
\hline Theoretical knowledge of physical culture & 50.9 & 56.9 & 51.4 & 90 & 39.8 \\
\hline
\end{tabular}

Note: Value of $p$ for the $x^{2}$ test was marked as follows: ${ }^{*} p \leq 0.05$

Statistically significant differences were found in the expectations of current and former athletes and nonathletes with regard to motivating schoolchildren to work (value of $p \leq 0.05$ for the $x^{2}$ test). The majority of former athletes and non-athletes indicated this psycho-pedagogical competence as the most important ( $86.1 \%$ and $86.4 \%$ respectively). Regarding the other competences indicated, no differences were observed with: shaping schoolchildren's self-evaluation of physical fitness and health, interpersonal communication techniques, activating techniques and methods, schoolchildren team management, shaping schoolchildren's sport-oriented attitudes, clarifying objectives that should be achieved by the teacher. In each case they were chosen by more than $50 \%$ (Table 3).

Tahle 3. Expectations of psycho-pedagogical competences among current and former athletes and non-athletes

\begin{tabular}{|c|c|c|c|c|c|}
\hline \multirow{3}{*}{ Psycho-pedagogical competences } & \multicolumn{3}{|c|}{ Student categories } & \multicolumn{2}{|c|}{ Total $(n=226)$} \\
\hline & $\mathrm{CA}(\mathrm{n}=51)$ & $\mathrm{FA}(\mathrm{n}=72)$ & $N A(n=103)$ & \multirow{2}{*}{$\mathrm{n}$} & \multirow{2}{*}{$\%$} \\
\hline & & $\%$ & & & \\
\hline Motivating schoolchildren to work* & 76.4 & 86.1 & 87.3 & 191 & 84.5 \\
\hline Shaping schoolchildren's self-evaluation of physical fitness and health & 74.5 & 66.6 & 56.3 & 144 & 63.7 \\
\hline Using interpersonal communication techniques & 66.6 & 31.4 & 44.2 & 140 & 61.9 \\
\hline Schoolchildren team management ability & 56.8 & 59.7 & 59.2 & 133 & 58.8 \\
\hline Using activating techniques and methods & 62.7 & 58.3 & 56.3 & 132 & 58.4 \\
\hline Shaping schoolchildren's sport-oriented attitudes & 60.7 & 58.3 & 48.5 & 123 & 54.4 \\
\hline Clarifying objectives that should be achieved by the teacher & 62.7 & 50.0 & 48.5 & 118 & 52.1 \\
\hline
\end{tabular}

Note: Value of $p$ for the $x^{2}$ test was marked as follows: ${ }^{*} p \leq 0.05$ 


\section{General self-evaluation of specialist and psycho-pedagogical competences}

Respondents rated their own specialist competences as good, average and very good (68\%, $22.9 \%$ and $9.1 \%$ respectively). No correlations were observed concerning the self-evaluation of specialist competences of current and former athletes and non-athletes.

Statistically significant differences were found concerning the self-evaluation of psycho-pedagogical competences of current and former athletes and non-athletes (value of $p \leq 0.001$ for the $x^{2}$ test) (Figure 1). Among non-athletes, most people were characterized by a good and average evaluation of their own psycho-pedagogical competences ( $50.5 \%$ and $43.4 \%$ respectively). Current athletes mostly rated these competences as good and very good ( $64.7 \%$ and $14.8 \%$ respectively). Former athletes' proportions of average and good self-evaluations were similar $(37.1 \%$ and $42.8 \%)$. At the same time, this group had the greatest number of respondents with the highest self-evaluation (20.1\%).

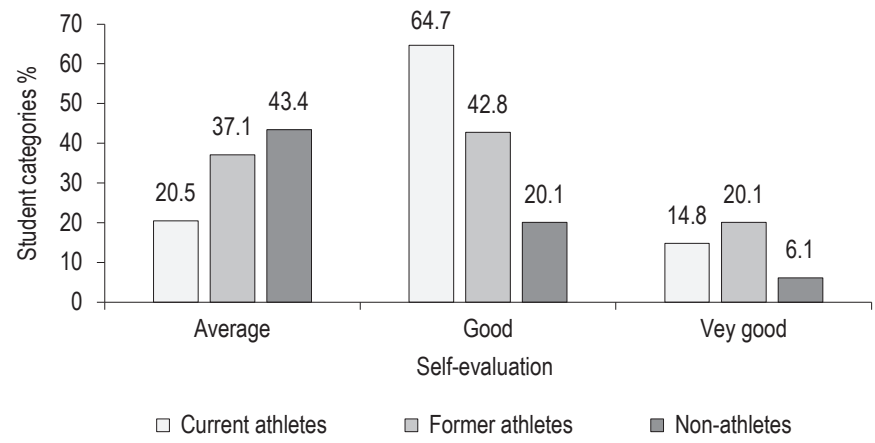

Figure 1. Self-evaluation of psycho-pedagogical competences among current and former athletes and non-athletes $\left(p \leq 0.001\right.$ for the $x^{2}$ test)

\section{Self-evaluation of the preparation for employment with respect to chosen competences indicated by the students}

Statistically significant differences were found concerning the self-evaluation of competences with respect to development of an athletic career (value of $p \leq 0.001$ for the $x^{2}$ test), knowledge of foreign languages (value of $p \leq 0.01$ for the $x^{2}$ test), preparation for scientific work, self-education ability and computer skills (value of $p \leq 0.05$ for the $\chi^{2}$ test in each case) among current and former athletes and non-athletes (Table 4).

The lowest self-evaluation of competences related to planning and development of an athletic career while studying was reported by non-athletes (fair by $41 \%$ ). A good and very good levels of these competences were indicated by current and former athletes ( $58.4 \%$ and $51.5 \%$ respectively).

Most respondents rated their own preparation for scientific work as average $(55.8 \%)$. This preparation was most often rated as fair by non-athletes, and as good by current athletes ( $26.7 \%$ and $37.5 \%$ respectively). 
Table 4. Self-evaluation of the quality of the preparation for employment among current and former athletes and non-athletes

\begin{tabular}{|c|c|c|c|c|c|c|}
\hline \multicolumn{2}{|c|}{ Self-evaluation of preparation for employment } & \multicolumn{3}{|c|}{ Student categories } & \multicolumn{2}{|c|}{ Total $(n=215)$} \\
\hline Self-evaluation elements & Scale 1-5 & $\mathrm{CA}(\%)$ & $\mathrm{FA}(\%)$ & NA (\%) & $\mathrm{n}$ & $\%$ \\
\hline \multirow{4}{*}{ Development of an athletic career*** } & Fair & 14.5 & 16.6 & 41.0 & 59 & 27.5 \\
\hline & Average & 27.1 & 31.9 & 36.0 & 70 & 32.7 \\
\hline & Good & 39.5 & 37.9 & 20.0 & 64 & 29.9 \\
\hline & Very good & 18.9 & 13.6 & 3.0 & 21 & 9.9 \\
\hline \multirow{3}{*}{ Preparation for scientific work ${ }^{*}$} & Fair & 14.6 & 13.6 & 26.7 & 43 & 43 \\
\hline & Average & 47.9 & 65.1 & 53.4 & 120 & 55.8 \\
\hline & Good & 37.5 & 21.3 & 19.9 & 52 & 24.1 \\
\hline \multirow{4}{*}{ Self-education ability* } & Fair & 8.3 & 1.7 & 7.9 & 13 & 6.0 \\
\hline & Average & 15.1 & 18.1 & 12.5 & 54 & 25.1 \\
\hline & Good & 62.5 & 57.5 & 63.0 & 117 & 54.4 \\
\hline & Very good & 14.1 & 22.7 & 16.6 & 31 & 14.4 \\
\hline \multirow{4}{*}{ Knowledge of foreign languages ${ }^{* *}$} & Fair & 39.5 & 24.2 & 53.4 & 60 & 27.9 \\
\hline & Average & 23.0 & 19.7 & 14.5 & 59 & 27.4 \\
\hline & Good & 23.0 & 40.9 & 25.2 & 72 & 33.5 \\
\hline & Very good & 14.5 & 15.2 & 6.9 & 24 & 11.2 \\
\hline \multirow{4}{*}{ Computer skills* } & Fair & 11.7 & 12.3 & 2.1 & 18 & 8.5 \\
\hline & Average & 18.9 & 16.6 & 25.2 & 47 & 22.1 \\
\hline & Good & 41.3 & 43.9 & 40.4 & 88 & 41.3 \\
\hline & Very good & 28.1 & 27.2 & 32.3 & 60 & 28.1 \\
\hline
\end{tabular}

Note: Value of $p$ for the $x^{2}$ test was marked as follows: ${ }^{*} p \leq 0.05,{ }^{* *} p \leq 0.01,{ }^{* * *} p \leq 0.001$. A Likert scale was used $1-5$, where 1 stands for 'insufficient' and 5 for 'very good'. The lowest evaluations were not reported.

More than half of the students examined rated their self-education ability as good (54.4\%). Among current athletes and non-athletes there were more instances of rating self-education ability as fair $(8.3 \%$ and $7.9 \%$ respectively).

Knowledge of foreign languages was rated as fair and average by most of current athletes and non-athletes (62.5\% and $67.9 \%$ respectively). Good and very good evaluation of knowledge of foreign languages was more often reported by former athletes (56.1\%).

Competence related to computer skills was rated as good by $41.3 \%$ of all the students. A very good evaluation of this competence was more often indicated by non-athletes $(32.3 \%)$, among whom there were at the same time fewer people who rated it as fair $(2.1 \%)$.

\section{Discussion and conclusions}

In a study of students of a physical education university, it was found that while making the choice of their field of study the respondents were driven mainly by the group of sport-related motives (athletic predispositions, practicing sports at competitive level). To a lesser extent they considered employment-related motives (the prospect of working as a physical education teacher, working with youth, having a job connected with physical culture) (Brojek, Zajkowska-Magier, 2004). In a study by other authors, the main motives for the choice of the field of study cited by respondents concerned the desire to go into one of the following professions: physical education teacher, 
health promotor, coach, sports manager. At the same time they expressed the conviction that studying in this field was attractive (Kumala, 2011; Radzińska et al., 2013).

It was found that having athletic predispositions, the prospect of an interesting job (including work in school or institutions of physical culture), and being interested in physical recreation were the most important motives for the choice of the studies. Choosing the field of physical education, students expected an interesting job, but only $16.3 \%$ thought of working in school and $19.4 \%$ of working in the institutions of physical culture. Thus the hypothesis was confirmed partially. An important motive for the choice of the studies was the conviction of their attractiveness. Results corresponding to the present ones have been produced in research by other authors (Buchta, 2012). The conviction of a high prestige of the teaching profession, the desire to follow one's physical education teacher's example, and friends and acquaintances' persuasion, were least often mentioned motives (Zowczak, 2009; Gliński, 2014).

The complicated socio-demographical situation in Poland, as well as constant changes in the educational system and the system of training teachers do not make employment in schools attractive (Day, 2004). The fourth hour of physical education, implemented in accordance with the Core Curriculum (http://www.reformaprogramowa. men.gov.pl; 15.10.2015), should, on the one hand, foster creation of new jobs; on the other hand, however, the current demographic decline makes it difficult to find a job in school, and diminishes the prospect of positive change in the future. The situation is also unclear concerning the announcements of changes in Polish people's pension entitlement, and another educational system reform involving elimination of junior high schools and changes in the core curriculum at all stages of education (sejm.gov.pl/2015.pdf; 18.12.2015).

In Wroclaw research, $15 \%$ of female and $20 \%$ of male students declared that they would not work as physical education teachers; others (46\%) consider this possibility only if they did not find another, more attractive job (Lewandowski, Starościak, Guła-Kubiszewska, 2011). In many European countries the problem of a declining social standing of teachers is observed. The results of the Teaching and Learning International Survey (TALIS 2013), indicate a complicated professional and social status of teachers. Out of 172 thousand teachers included in the survey, only $18 \%$ declared that their profession is respected. The same survey also reveals factors affecting the decline in the prestige of the profession, which include social changes, lack of public awareness of the specifics of teachers' work, low pay, a negative influence of the media, a poor quality of teachers' training, parents' negative perception of teachers' work (http://eduentuzjasci.pl/badanie/599-talis; 4.12.2015). The present study confirmed a low standing of the profession of a physical education teacher.

Determining the full set of professional competences looked for in a physical education teacher is not simple, although defining them could be helpful in the modernization of the training process of students in this field (Paczyńska-Jędrycka, Łubkowska, 2013; Łubkowska, 2015). Today's requirements concerning employment, make it necessary that in addition to professional skills related to the job profile, candidates also have social skills, including collaboration, communication and negotiation capabilities. In the above study, the ability to use basic elements of the teacher's expertise was considered the most important.

Students included in the study considered methodological knowledge and skills related to physical education, recreation and chosen sports disciplines to be the most important specialist competences. These results confirm the hypothesis. Competences concerning a high level of physical fitness and theoretical knowledge of physical culture, on the other hand, were of lesser significance. A study of praxeological competence in pedagogical and methodological knowledge concerning effective teacher's performance produced similar results (Skibniewski, 
2011). In the present study it was found that competence in physical fitness was of greater importance for subjects who currently practiced sports at a competitive level.

In the opinion of surveyed elementary school teachers, the most important specialist professional competences of a teacher are methodological skills and knowledge in the field of broadly understood physical culture; significant psycho-pedagogical competences, in turn, are a positive attitude toward schoolchildren, communication skills and motivating schoolchildren to work creatively (Radzińska, Fiedor, 2007; Zalech, 2011; Kyrgyrdis, Derri, 2006). In the present study, only the hypothesis concerning competence in motivating schoolchildren to work was confirmed. The greatest importance was attached to this competence by non-athletes and former athletes.

Self-evaluation can concern different aspects of man's actions, knowledge, abilities, attitudes, competences. Apart from students' expecting specific competences, which they considered important, they were aware of certain areas of their own incompetence. They admitted their fair or average knowledge of foreign languages and preparation for scientific work (research). Undoubtedly, a positive accent could be seen in the self-evaluation of the self-education ability, which was considered well-mastered. It can be assumed that the surveyed students had the readiness for continuous professional development and complementing their competences achieved through University studies, which is also confirmed by other research (Buchta, 2009; Kijo, 2007).

The demands of the labor market and the competitiveness of the educational offers of different universities result in a growing interest in the issues of education quality and equipping students with the competences expected by external interested parties. The necessity for the above study to be cyclical stems, among others, from the provisions of the Bologna Declaration, one of the objectives of which is to create the European Higher Education Area, as well as from responsibility toward the academic community and the country.

The problem of students quitting their sports training on commencing studies at a physical education university is beyond the scope of this study. Despite student athletes' having individual studying schedules, practicing sports at a high level is not conducive to studying at universities of physical education. Finding the causes of this situation will be the subject of subsequent research.

\section{Conclusions}

1. Most people's reasons for the choice of physical education studies were: having athletic predispositions, the prospect of an interesting job, being interested in physical recreation, possibilities for self-realization and development of an athletic career. Former athletes more often reported having been motivated to choose this field of study by their interest in employment with institutions of physical culture. Non-athletes declared they had made the choice because of their wish to obtain jobs in schools.

2. Expectations of competence in knowledge and skills concerning physical education methodology were indicated by all respondents, but slightly more often by former athletes and non-athletes. For current athletes, who present a high level of performance in their disciplines, expectations of increasing their competence in physical fitness were more important than for other students.

3. Most respondents indicated motivating schoolchildren to work as the most important psycho-pedagogical competence they expected to gain during their studies. Its significance was stressed more often by former athletes and non-athletes. 
4. Respondents rated their preparation for employment with regard to their self-education ability and computer skills as good. Competences concerning their knowledge of foreign languages and preparation for scientific work were rated as average and fair.

\section{References}

Brojek, A., Zajkowska-Magier, M. (2004). Motywy wyboru studiów wychowania fizycznego. Rocznik Naukowy ZWWF w Białej Podlaskiej, 11, 63-79.

Buchta, K. (2009). Quality of education from the prospective of a student of University of Physical Education. Pol. J. Sport Tourism, $16,39-48$.

Buchta, K. (2012). The competences of physical education students. Unified versus two-tier University studies. Pol. J. Sport Tourism, $19,151-159$.

Cieśliński, R. (2009). Uczelniany system jakości kształcenia - założenia a praktyka w kontekście procesu bolońskiego. Pol. J. Sport Tourism, 16, 135-142.

Czerepaniak-Walczak, M. (2013). Autonomia w kolorze sepii w inkrustowanej ramie KRK. O procedurach i treściach zmiany w edukacji akademickiej. In: M. Czerepaniak-Walczak (ed.), Fabryki dyplomów czy universitas? (pp. 29-54). Kraków: Impuls.

Day, Ch. (2004). Rozwój zawodowy nauczyciela. Gdańsk: GWP.

Eider, J. (2009). Physical education faculty in Western Pomerania. Zeszyty Naukowe Uniwersytetu Szczecińskiego nr 583. Prace Naukowe Instytutu Kultury Fizycznej, 26, 57-72.

Erikson, E.H. (2004). Tożsamość a cykl życia. Poznań: Zysk i S-ka.

Ferenz, K. (2010). Edukacja całożyciowa człowieka w świetle zadań rozwojowych. In: M. Kowalski, M. Olczak (eds.), Edukacja w przebiegu życia od dzieciństwa do starości (pp. 28-45). Kraków: Impuls.

Gliński, M. (2014). Preferencje zawodowe a stres zawodowy wśród nauczycieli. Psychologia Wychowawcza, 6, 37-54.

Hamer, H. (1994). Klucz do efektywności nauczania. Warszawa: Veda.

http://eduentuzjasci.pl/badanie/599-talis (14.12.2015).

http://www.reformaprogramowa.men.gov.pl (15.10.2015).

Jagusz, M. (2011). Oczekiwania ucznia w zakresie kompetencji nauczyciela. Rozprawy Naukowe Akademii Wychowania Fizycznego we Wrocławiu 35, 66-69.

Kijo, P. (2007). Wzrastająca rola kompetencji pedagogicznych w kształceniu nauczycieli wychowania fizycznego. In: A. Kaźmierczak, A. Makarczuk, A. Maszorek-Szymala (eds.), Kultura fizyczna i zdrowotna w życiu współczesnego człowieka (pp. 110-115). Łódź: Wydawnictwo Uniwersytetu Łódzkiego.

Kotarska, K., Wunsch, E., Raszeja-Wyszomirska, J., Kempińska-Podhorodecka, A., Wójcicki, M., Milkiewicz, P. (2015). Leisure time physical activity and health-related behaviors after liver transplantation: a prospective, single centre study. Prz Gastroenterol, 10 (2), 100-104. DOI: 10.5114/pg.2015.49002.

Kraśniewski, A., Próchnicka, M. (2013). Benchmarking procesu wdrażania Krajowych Ram Kwalifikacji w polskich uczelniach. Warszawa: Fundacja Rektorów Polskich.

Kraśniewski, A. (2004). Proces Boloński: dokąd zmierza europejskie szkolnictwo. Warszawa.

Kumala, R. (2011). Nauczyciel wychowania fizycznego - opinie kandydatów na studia we wrocławskiej Akademii Wychowania Fizycznego. Rozprawy Naukowe Akademii Wychowania Fizycznego we Wrocławiu, 35, 57-60.

Kwiatkowska, H. (2008). Pedeutologia. Warszawa: PWN.

Kyrgyrdis, P., Derri, V. (2006). Factors that contribute to effective teaching in physical education. A. Review. Inquiries in Sport and Physical Education, 4 (3), 409-420.

Lewandowski, M., Starościak, W., Guła-Kubiszewska, H. (2011). Przygotowanie studentów AWF we Wrocławiu do pełnienia funkcji nauczyciela wychowania fizycznego. Rozprawy Naukowe Akademii Wychowania Fizycznego we Wrocławiu, 53, 40-44.

Łubkowska, W. (2015). Young people's lifestyle as a determinant of future health of the society, based on tourism and leisure students from the University of Szczecin. In: Health and Physical Activities in Lifestyle among Children and Youth (pp. 27-39). Banská Bystrica: International Scientific Conference Conference Textbook of Invited Lectures Eds. 
Paczyńska-Jędrycka, M., Łubkowska, W. (2013). Adventure/qualified tourism in the rehabilitation of juveniles. Centr Eur J Sport Sci Med., 3, 31-32.

Radzińska, M., Fiedor, M. (2007). Standardy kompetencji zawodowych nauczyciela wychowania fizycznego warunkujących efektywność procesu kształcenia i wychowania fizycznego, In: W.J. Maliszewski (ed.), Komunikacja społeczna a wartości w edukacji. Nowe znaczenie i sytuacje. Szkolna przestrzeń interakcji i działań komunikacyjnych (pp. 222-227), Toruń: Wydawnictwo Marszałek.

Radzińska, M., Nowak, M., Nowak, L. (2013). Choice motivation of physical education and proffesional interests of future experts in physical education. Teoriya i Praktika Fizicheskoy Kultury, 5, 103-106.

Salmela-Aro, K., Tolvanen, A., Nurmi, J.-E. (2009). Achievement strategies during university studies predict early career burnout and engagement. Journal of Vocational Behavior, DOI: 10.1016/j.jvb.2009.03.009.

sejm.gov.pl/Druki7ka.nsf/Projekty/pdf (18.12.2015).

Skibniewski, S. (2011). Kompetencje pedagogiczne studentów kończących studia wychowania fizycznego. Rozprawy Naukowe Akademii Wychowania Fizycznego we Wrocławiu, 25, 77-80.

Telama, R., Laakso, L., Yang, X. (1994). Physical activity and participation in sports of young people in Finland. Scand J Med. Sci Sports, 4, 65-74. Article first published online: 30 JAN 2007. DOI: 10.1111/j.1600-0838.1994.tb00407.x.

Telama, R., Xiaolin, Y., Laakso, L., Viikari, J. (1997). Physical activity in childhood and adolescence as predictors of physical activity in young adulthood. Am J Prev Med, 3 (4), 317-323.

Van Buurren, J., de Leeuw, J.V. (1992). Equality Constrains in Multiple Correspondence Analysis. Multiv. Behav. Res., 67-83.

www.bip.gov.pl (10.11.2015).

www.reformaprogramowa.men.gov.pl (15.10.2015).

Zalech, M. (2011). Elimination of negative character features as an element of building a positive image of physical education teacher. Pol. J. Sport Tourism, 18, 206-213.

Zowczak, J. (2009). Motywy wyboru zawodu nauczycielskiego w warunkach polskiej transformacji - perspektywa socjologiczna. In: K. Chałas, B. Komorowska (eds.), Kreowanie tożsamości szkoły, t. 2: Konteksty historyczne, społeczno-kulturowe i edukacyjne (pp. 239-249). Lublin: KUL.

Cite this anticle aS: Radzińska, M., Nowak, L., Nowak, M.A. (2016). Motives for Commencing Studies and Expectations Concerning Professional Competence in Students who Practice, Used to Practice or Have Never Practiced Sports. Central European Journal of Sport Sciences and Medicine, 13 (1), 37-47. DOI: 10.18276/cej.2016.1-04. 
